TP Periodica Polytechnica

Transportation Engineering

45(3), pp. 162-167, 2017

https://doi.org/10.3311/PPtr.10743

Creative Commons Attribution (i)

RESEARCH ARTICLE

\section{A Study on the Government Subsidies for CR Express Based on Dynamic Games of Incomplete Information}

\author{
Qiwen $\mathrm{Du}^{1}$, Xianliang Shi ${ }^{*}$
}

Received 13 December 2016; accepted 21 March 2017

\begin{abstract}
CHINA RAILWAY Express (CR express) refers to the international container train running in the East Asian Economic Circle and the developed European Economic Circle, and it is an important link in the development of "The Belt and Road". However, as CR Express is still in the early stages of development, it is still on the way to fully market-oriented operations, and also has some problems such as high overall transportation cost, disorderly competition and other issues. From the perspective of government subsidies, this paper by searching the relationship in incomplete information dynamic game between local government and local relevant enterprises, gets the optimal subsidy amount for the government to obtain the maximum social benefit. The results can provide a reference for the government to formulate a reasonable subsidy policy and for the CR express to realize market-oriented.
\end{abstract}

\section{Keywords}

CHINA RAILWAY Express, government subsidies, dynamic game, social benefit

${ }^{1}$ School of Economics and Management, Beijing Jiaotong University, Beijing, China

${ }^{*}$ Corresponding author, e-mail: 14113135@bjtu.edu.cn

\section{Introduction}

CHINA RAILWAY Express which is organized by China Railway Corporation, refer to the international container train running between China, Europe and other countries which involve in "The Belt and Road"; these trains runs in fixed trip, line, schedule and total run time, serving as an initiative carrier that deepens the economic and trade cooperation between China and the involved countries, and thus is also an important link in the "the Belt and Road". By the end of June 2016, CR express has accumulated totally 1881 runs, while 502 of those are return trains; there are 16 cities of originating departure in China and 12 overseas stops, 39 operation lines, and approximately \$17 billion of total volume of import and export trade. The Service Platform of CHINA RAILWAY Express has been in operation, the scope of services is expanding, and the service capability is also being steadily enhanced. The 3 transport corridors in west, central and east have been paved. The west corridor now has included 20 lines of train within China; these lines entering and leaving the border through Alataw Pass and Horgas Pass mainly transport the imports and exports goods between the Mid-western Region of China and Europe; the central corridor now has launched 3 lines of train within China; these lines entering and leaving the border through Erenhot port mainly transport the imports and exports goods between the northern area of East China, the central section of East China and Europe; the east corridor now has paved 14 lines of train within China, these lines entering and leaving the border through Manchuria port mainly transport the imports and exports goods between the East China, Southern China coast, Northeast China and Europe.

At present, the running time for the whole course of CR Express is about 16 days, and the transit time is about 20 days less than shipping, but the cost of transportation is about 10 thousand US dollars for per FEU, which is two times of shipping (see Table 1). So, if only the transport costs is considered, CR Express is not as good as the traditional shipping, but the transport cost and transport time should be considered at the same time in choosing the transport route. So when the transit time costs of high value added goods is taken into consideration (Theofanis and Boile, 2009; Jayaram et al., 1999). 
Table 1 The comparison of the cost between CR Express and traditional shipping

\begin{tabular}{|c|c|c|c|c|c|c|}
\hline \multirow{2}{*}{\multicolumn{2}{|c|}{ Type of transport }} & \multirow{2}{*}{ Route of transport } & \multirow{2}{*}{$\begin{array}{l}\text { Cost of } \\
\text { transport }\end{array}$} & \multirow{2}{*}{$\begin{array}{l}\text { Time for } \\
\text { transport }\end{array}$} & \multicolumn{2}{|c|}{ Total cost } \\
\hline & & & & & High time sensitivity & Low time sensitivity \\
\hline \multirow{2}{*}{$\begin{array}{l}\text { Marine } \\
\text { transport }\end{array}$} & $\begin{array}{c}\text { River-sea Coordinated } \\
\text { Transport }\end{array}$ & $\begin{array}{c}\text { Chongqing - Shanghai - } \\
\text { Hamburg }\end{array}$ & 4000 & 40-45 days & 23200 & 8800 \\
\hline & Rail-sea transport & $\begin{array}{c}\text { Chongqing - Shenzhen - } \\
\text { Hamburg }\end{array}$ & 5000 & 28-36 days & 18400 & 8360 \\
\hline \multirow{2}{*}{$\begin{array}{l}\text { Railway } \\
\text { transport }\end{array}$} & $\begin{array}{c}\text { Chongqing - Xinjiang } \\
\text { - Europe }\end{array}$ & $\begin{array}{c}\text { Chongqing - Alataw Pass } \\
\text {-Duisburg }\end{array}$ & 9700 & 15-17 days & 16900 & 11500 \\
\hline & $\begin{array}{c}\text { Chongqing - } \\
\text { Manchuria - Europe }\end{array}$ & $\begin{array}{c}\text { Chongqing - Manchuria } \\
\text {-Duisburg }\end{array}$ & 8300 & 13-15 days & 14540 & 9860 \\
\hline
\end{tabular}

CR Express has its own competitive edge. The typical CR Express lines include "Chongqing - Xinjiang - Europe line", "Wuhan - Xinjiang - Europe line", "Zhengzhou - Europe line", "Yiwu - Xinjiang - Europe line", "Yingkou - Manchuria Europe line", etc., they have distinct characteristics in terms of freight hinterland, transportation organization, operation mode, government subsidies and so on. For example, the "Chongqing - Xinjiang - Europe" Express is the most mature line, and it is the most convenient in leaving the country; the "Zhengzhou - Europe" Express has the widest range of radiation and the highest amount of subsidies; the "Yiwu - Xinjiang - Europe" Express has the longest mileage, etc.

Although CR express is an important carrier to deepen the economic and trade cooperation between China and the countries along and an important link in the development of "The Belt and Road", in the current operation, it is still entangled with the problems such as: lacking freight demand, especially lacking return freight demand; the procedure of leaving the country needs to be simplified, overall transport costs is high; transportation infrastructure and supporting services are inadequate, etc.

\section{Related research}

For the present, although the freight volume of CR express accounts for only $3 \%-5 \%$ of China- EU trade, the rate is growing significantly. In 2016, CR express runs for 1702 trains, and year-on-year growth is $109 \%$, of which 572 of them are the return trains, year-on-year growth of which is up to $116 \%$ (Data sources: China Railway Corporation). On the problem of the empty container allocation, which is caused by the imbalance of international trade, the scholars have done a lot of research. Hanh (2003) has done a detailed research on the container logistics practice of Los Angeles and southern California in the United States in his report, Theofanis (2009) has got a more comprehensive description of the container logistics practice from the spatial levels of global, interregional, regional, local. Shintani (2007) uses heuristic algorithm to prove that the revenue of service network can be increased by considering empty container scheduling and rental when design the transport network. Imai (2009) compares two typical types of liner network hub and spoke (H\&S) and multiport calling (MPC), and analyze advantages and disadvantages of these two kinds of network, from the perspective of the container (including the empty container scheduling cost point). Meng (2011) does more research based on Imai's research, and he thinks that $\mathrm{H} \& \mathrm{~S}$ is better than MPC on the perspective of costs.

The main difficulty to promote the facilitation of leaving the country is that $\mathrm{CR}$ express stretches across the China-Europe continent, passes by many countries and regions, and the level of economic and the infrastructure facilities of these countries are different. The facilitation of leaving the country involves many countries and a variety of gauges, and it is difficult to be solved in a short time, so this paper will not study this area.

High cost is an important issue in the operation of $\mathrm{CR}$ Express. For the international trade between Mid-West China and European countries, the short transport time of CR Express is an obvious advantage, so it is a good choice to use CR Express. However, due to various reasons, the costs of running CR Express are still relatively high; thus the current line of freight trains need to be subsidized by the local government to ensure normal operation (Nash, 2010; Abramovics et al., 2016). For example: for the Hefei - Xinjiang - Europe" line, the government subsidies each TEU on the foreign trade enterprises 2000 Yuan, and each TEU for the freight forwarding business 6000 Yuan; Chengdu subsidies the transport costs in the form of special funds; Chongqing subsidies to the local notebook producers in the direct reference of the shipping price; the subsidies of Wuhan also is almost the same as shipping price; Zhengzhou subsidies to the Express companies in the reference of the shipping price, at the same time the supply of goods within $1500 \mathrm{~km}$ can be freely transported to Zhengzhou.

Scholars have much researches on government subsidies. Sheu (2011) uses asymmetric Nash game model with uncertainty to study on the business negotiations and cooperation between the recycler and producer in green supply chain under the government intervention; the result shows that government intervention measures significantly affect the bargaining among the members 
in the supply chain. Hong (2011) discusses the problem of recycling cost and government subsidy in the reverse supply chain of electronic products; he constructs the game model between government and manufacturers, and determines the optimal amount of government subsidy under the goal of maximizing social welfare. Cowie (2002) chooses the chartered British Railways as an example, pointing that the economic subsidy should be able to guarantee the railway service level to reach the expectation of the society in the open market environment; at the same time, the government should reduce the amount of subsidies year after year, to promote railway companies to generate income. Russell (2007) holds that the key to the high efficiency of subsidies is how to make the unit price. The economics of marginal cost pricing rules require the price to be set at the level of marginal cost. But the fixed cost of railway transportation is very high, which means that the marginal cost is lower than the average cost, if use marginal cost pricing rules, the fixed cost will be irreparable. In Western European countries, governments subsidy for the maintenance and investment infrastructure aiming to achieve marginal cost pricing. However, while government subsidies will bring incentives to railway operations, the government, especially in developing countries, will have enormous financial pressure. If use the average cost level pricing, the huge financial pressure on the government can be avoided, but the loss of social welfare cannot be avoided. The way to solve these problems is to implement price discrimination, which can recover the fixed cost, and reduce the welfare loss as far as possible from the marginal cost pricing (Pittman, 2007). However Nash (2010) considers that the government is obliged to provide stable financing for railway infrastructure managers, by direct payment of the cost of the marginal benefit, or by agreeing to a price above the marginal cost, or subsidies from the both.

From now on, only few Chinese scholars have studied on the problems of government subsidies in CR Express; mostly, these scholars research from a macro perspective, instead of the reasonable subsidies in a quantitative way. This paper will use the way of dynamic games of incomplete information (Gibbons, 1992) to analyze the game behavior between the government and the local companies of CR Express, to study the government subsidy policy which is beneficial to the operation of the CR Express, and to provide some theoretical suggestions for the government.

\section{Basic assumptions of the model}

The government hands the CR Express project over to the enterprise, and the two parties have a principal-agent relationship. Due to the fact that CR Express is in the very early stages, it has not yet been in fully market-oriented operation, with the government subsidizing part of the container freight.

In the game system composed of the government and CR Express (hereafter this text will be abbreviated as "enterprise"), both parties pursue the maximization of their own interests. The government expects to use few subsidies to achieve greater social utility; companies expect to achieve maximum benefits with less effort and lower costs while gaining government subsidies.

Assuming that compared to the government, enterprises have more comprehensive and accurate market operation information, which means information is asymmetry between government and enterprises. Therefore, this paper studies the dynamic game of incomplete information between government and enterprises. The game model is formed of three stages:

Stage 1: Government subsidy scheme.

Stage 2: Enterprises choose whether to accept the commission (run the CR Express).

Stage 3: The enterprises determine efforts in operation.

In order to solve the problem, the model makes the following assumptions:

1. When the enterprises adopt different operating effort (the degree of effort represented by $x, x \geq 0$ ), there is a big difference in the level of service. The higher the level of effort is, the higher the level of service will be. Suppose that the degree of enterprise effort is linear with the service level:

$$
\mathrm{F}=a \mathrm{x}+\gamma
$$

a $>0$, means the degree of effort is positively correlated with the level of service; $\gamma$ means the mean value is 0 , variance is the normal random variable of $\sigma^{2}, \gamma$, means the influence of external environment on service level.

2. The degree of effort of the enterprise is related to its operating cost, assuming that the operation cost and effort level is a quadratic relationship:

$$
\mathrm{C}=\mathrm{b} x^{2}+C_{0}
$$

Among them, $C$ is the operating costs for the enterprise, $b$ is the cost coefficient, $b>0, C_{0}$ is the fixed cost for the enterprise.

3. Government subsidies to enterprises are related to the service level of enterprises, assuming that:

$$
\mathrm{B}=\alpha+\beta(\mathrm{F}-\bar{F})
$$

Among them, $B$ is the government subsidies, $\alpha$ is subsidies for the base, $\beta$ is the subsidy coefficient, $\alpha, \beta>0, \bar{F}$ is the minimum level of service for the government.

\section{The construction and solution of the model}

According to the three stages of the game between the government and the enterprise, the model is set up in stages as following.

\subsection{Government subsidy scheme}

The benefits of government can be understood as social benefits, and social benefits can be quantified by using the theory of consumer surplus and producer surplus. In this game model, the government's revenue function can be expressed as: 


$$
U_{1}=P_{S}+C_{S}-I
$$

Among them, $U_{1}$ means the government revenue, $P_{S}$ means producer surplus, $C_{S}$ means consumer surplus, $I$ means the cost of external effects.

Producer surplus, means the operation of the central bank operating income in this study, so it can be expressed as:

$$
P_{S}=Q p+B-C
$$

Among them, $Q$ is the freight volume of CR Express, and $p$ is the freight rate of CR Express.

Consumers' surplus, in this study refers to the D-value between the maximum price of the shipper's willingness to pay and the actual rate of payment, so $C_{S}$ can be expressed as:

$$
C_{S}=Q(\mathrm{~m}-\mathrm{p})
$$

Among them, $\mathrm{m}$ is the highest price that the shipper is willing to pay.

In summary, function of government revenue can be expressed as:

$$
U_{1}=Q p+B-C+Q(\mathrm{~m}-\mathrm{p})-I
$$

That is,

$$
U_{1}=Q m+B-C-I
$$

The problem that the government faces is to make a reasonable decision to the subsidize, so that the enterprise will accept the operation commission of the government, to achieve the maximum utility of the government, at the same time to encourage enterprises to actively operate.

\subsection{Agency by agreement}

The income of the enterprise mainly includes the freight paid by the shipper and the subsidy from the government. The cost of company is mainly operating costs. The container transportation volume $Q$ is directly related to the price of container and the degree of effort of the enterprise. Assuming that the expression of $Q$ is:

$$
\mathrm{Q}=q_{0}+q_{1} x-q_{2} p^{2}
$$

In the formula is the fixed volume of the container, $q_{0}$ is the coefficient of volume of business operation, $q_{1}$ is the coefficient of utilization of container freight, $q_{1}, q_{2}$ are more than 0 .

So the income function of the enterprise can be expressed as:

$$
U_{2}=\left(q_{0}+q_{1} x-q_{2} p^{2}\right) \mathrm{p}+\mathrm{B}-\mathrm{C}
$$

The enterprise can also refuse or choose other agent in the second stage of the game, so there is an opportunity benefit, this paper uses the average profit level of the industry replace the opportunity benefit, only $U_{2} \geq \bar{\mu}$ the enterprise will accept the commission. That is:

$$
\left(q_{0}+q_{1} x-q_{2} p^{2}\right) \mathrm{p}+\mathrm{B}-\mathrm{C} \geq \bar{\mu}
$$

\subsection{The effort that the enterprises make}

Enterprises understand their own income function, so the degree of effort can be focused when they select, choose to make efforts which can gain the maximum operating income. That is:

$$
\max U_{2}=\max \left[\left(q_{0}+q_{1} x-q_{2} p^{2}\right) \mathrm{p}+\mathrm{B}-\mathrm{C}\right]
$$

In summary, the game model of government and enterprises in this study is:

$\max U_{1}=\max \left[\left(q_{0}+q_{1} x-q_{2} p^{2}\right) m+\alpha+\beta(a \mathrm{x}+\gamma-\bar{F})-\left(\mathrm{b} x^{2}+C_{0}\right)-I\right]$

s.t. $\left\{\begin{array}{c}\left(q_{0}+q_{1} x-q_{2} p^{2}\right) p+\alpha+\beta(a \mathrm{x}+\gamma-\bar{F})-\mathrm{b} x^{2}+C_{0} \geq \bar{\mu} \\ \max U_{2}=\max \left[\left(q_{0}+q_{1} x-q_{2} p^{2}\right) p+\alpha+\beta(a \mathrm{x}+\gamma-\bar{F})-\left(b x^{2}+C_{0}\right)\right]\end{array}\right.$

\subsection{Model solution}

The model is solved by backward induction. The first derivative of (3) can be obtained:

$$
\left(\mathrm{d} U_{-} 2\right) / \mathrm{dx}=p q_{-} 1+a x-2 b x
$$

Make it equal to 0 , then will get,

$$
x^{\wedge} *=\left(p q_{-} 1+a^{2}\right) / 2 b
$$

That is, after the enterprise accepting the commission of government, choose the maximum degree of effort to maximize enterprise income, take it into (1) and (2), can get:

$$
\begin{aligned}
\max U_{1} & =\max \left[q_{0}+q_{1} \frac{p q_{1}+a^{2}}{2 b}-q_{2} p^{2} m+\alpha+\beta\left(a \frac{p q_{1}+a^{2}}{2 b}+{ }^{3}-\bar{F}\right)\right. \\
& \left.-\left(b\left(\frac{p q_{1}+a^{2}}{2 b}\right)^{2}+C_{0}\right)-I\right]
\end{aligned}
$$

$$
\begin{aligned}
& \left(q_{0}+q_{1} \frac{p q_{1}+a^{2}}{2 b}-q_{2} p^{2}\right) p+\alpha+\beta\left(a \frac{p q_{1}+a^{2}}{2 b}+{ }^{3}-\bar{F}\right) \\
& -\left(b\left(\frac{p q_{1}+a^{2}}{2 b}\right)^{2}+C_{0}\right) \geq \bar{\mu}
\end{aligned}
$$

The first derivative of (4) can be obtained:

$$
\left(\mathrm{d} U_{-} 1\right) / \mathrm{d} \beta=\left(a m q_{-} 1+a^{\wedge} 2 \beta\right) / 2 b+\gamma-F^{-}
$$

Make it equal to 0 , can get the optimal government subsidy coefficient,

$$
\beta^{\wedge *}=\left(2 b\left(F^{-}-\gamma\right)-a m q_{-} 1\right) / a^{\wedge} 2
$$

According to the optimal government subsidy coefficient, under the goal of the government to get the best social benefit, the optimal amount of subsidies relate to the shipper that the highest of the enterprise is willing to pay, the service level of enterprises, the government specified minimum service level, enterprise business operation cost coefficient, effort level of enterprise and service level conversion coefficient, container quantity the business operation effected by the effort of enterprise and external random factors. 


\section{Numerical analysis}

The numbers set in the paper refers to the numbers of "Chongqing - Xinjiang - Europe" Chongqing - Alataw Pass -Duisburg (specific parameter values are shown in Table 2). For the convenience of calculation, the influence of random factors on the service level of enterprises is not considered. So under the goal of the government to get the best social benefits, the relationship between the amount of government subsidies B, the highest price $m$ which the shipper is willing to pay, and the degree of effort $\mathrm{x}$ is shown in Fig. 1 .

Table 2 Parameter settings

\begin{tabular}{ccc}
\hline $\begin{array}{c}\alpha \text { (Thousand } \\
\text { dollar/FEU) }\end{array}$ & $\begin{array}{c}\alpha \text { (Thousand } \\
\text { dollar/FEU) }\end{array}$ & $\begin{array}{c}m \text { (Thousand } \\
\text { dollar/FEU) }\end{array}$ \\
\hline 1 & 3 & $0<\mathrm{m}<20$ \\
$q_{1}$ & $\bar{F}$ & $a$ \\
0.2 & 0.5 & 0.9 \\
\hline
\end{tabular}

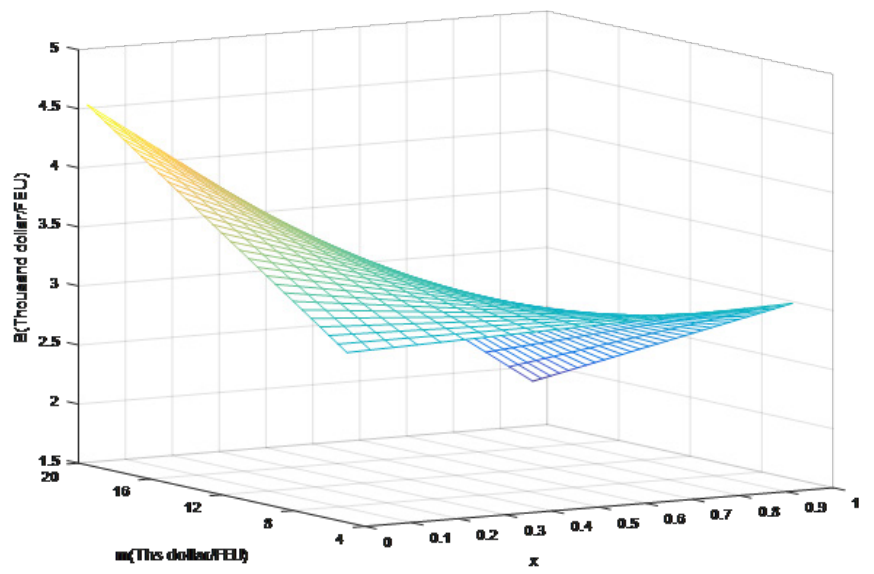

Fig. 1 The relationship between the amount of government subsidies and the highest price and the degree of effort that the enterprise is willing to pay

It is clear to see in Fig. 1, that in order to achieve the best social benefits, CR Express has a subsidy of 1.9 thousand dollars to 4.5 thousand dollars for per FEU. The amount of subsidy is related to the highest price and the degree of effort that the enterprise is willing to pay. When the degree of effort $x$ is less than 0.6 , the amount of government subsidies $B$ is positively related to the highest rate $m$; the smaller $x$ is, the stronger the correlation between $B$ and $m$ will be. When the degree of effort $x$ is greater than or equal to 0.6 , the amount of government subsidy $B$ is negatively correlated with the highest rate $m$, but with the increase of $x$, relevant of $B$ and $m$ is small. When the degree of effort of the enterprise $x$ is 0.95 , the highest price that the enterprise is willing to pay $m$ is 19.5 thousand dollars per FEU, the amount of subsidies $B$ reach the minimum value of 1.9 thousand dollars per FEU. And the region with the lowest $B$ value appeared in the region with larger $m$ value and $x$ value, it means that the higher the enterprise is willing to pay, the greater degree of efforts of the enterprise to spare, the government is more likely to get the maximum social benefits with the smaller subsidies to CR Express.

\section{Conclusion and prospects}

As the running of CR Express is in the early stages of the market, it has not yet fully realized market-oriented operation, and many local governments take out their respective subsidy policies to support the development of CR Express. Based on the dynamic game of incomplete information, this paper studies the Optimal Subsidy of local government to get the best social benefits. In the reference of the data of the "Chongqing - Xinjiang - Europe" Chongqing - Alataw Pass -Duisburg line, the numerical analysis is carried out. According to the research results, this paper puts forward the following policy recommendations for the local governments to make a reasonable plan for the subsidies to CR Express:

1. Different amount of subsidies for different value added container goods. In order to achieve a higher social benefit, the government needs to give a lower subsidy to the goods with high added value, especially, when the enterprise has a higher effort level; for the high value-added goods, the government can obtain higher social benefits in a lower amount of subsidies; but when the enterprise has a low effort level, in order to obtain a higher social benefits, the government needs to provide a higher amount of subsidies for low value-added goods.

2. Encourage enterprises to play the advantages of railway transport, and carry more high value-added goods. The railway transportation is faster than the traditional shipping, although the price is higher. So, CR Express is highly competitive in the high value-added goods, and shippers are willing to pay higher prices for goods with high added value. The government can achieve higher social benefits by encouraging enterprises to carry high value-added goods, in order to improve the maximum price limit that the shipper is willing to pay.

3. Encourage enterprises to improve service quality to set the "CR Express" brand. CR Express is the international logistics brand supported by the nation, the government should encourage enterprises to improve the quality of service, and jointly promote the development of CR Express brand. The government encourages enterprises to improve the quality of service in order to gain a higher level of effort; when the enterprises pay higher level of effort, the government is more likely to obtain higher social benefits in a lower amount of subsidies.

Based on the existence of government subsidies, the author studies the game relationship between the local government and the local enterprises of CR Express, and the author has not considered the withdrawal mechanism of government subsidies. Moreover, the research of this paper is less related to the 
shipper's expenditure and income. The future research direction is to consider the game relationships among the government, the enterprise and the shipper, and the optimal scheme and the exit mechanism of the government subsidies.

\section{References}

Abramović, B., Zitricky, V., Biškup, V. (2016). Organisation of railway freight transport: case study. CIM/SMGS between Slovakia and Ukraine. European Transport Research Review. 8(4), p. 27. https://doi.org/10.1007/s12544-016-0215-7

Cowie, J. (2002). Subsidy and Productivity in the Privatised British Passenger Railway. Economic Issues. 7(1), pp. 25-38.

Gibbons R. (1992). A primer in game theory. Harvester Wheatsheaf.

Hanh L D. (2003). The logistics of empty cargo containers in the Southern California region: are current international logistics practices a barrier to rationalizing the regional movement of empty containers. Metrans Final Report. METRANS Transportation Center. 2003.

Hong, I. H., Ke, J. S. (2011). Determining advanced recycling fees and subsidies in "E-scrap" reverse supply chains. Journal of Environmental Management. 92(6), pp. 1495-502. https://doi.org/10.1016/j.jenvman.2010.12.004

Imai, A., Shintani, K., Papadimitriou, S. (2009). Multi-port vs. Hub-and-Spoke port calls by containerships. Transportation Research Part E Logistics \& Transportation Review. 45(5), pp. 740-757. https://doi.org/10.1016/j.tre.2009.01.002

Jayaram, J., Vickery, S. K., Droge, C. (1999). An empirical study of timebased competition in the North American automotive supplier industry. International Journal of Operations \& Production Management. 19(10), pp. 1010-1034. https://doi.org/10.1108/01443579910287055
Meng, Q., Wang, S. (2011). Liner shipping service network design with empty container repositioning. Transportation Research Part E Logistics \& Transportation Review. 47(5), pp. 695-708. https://doi.org/10.1016/j.tre.2011.02.004

Nash, C. (2010). European rail reform and passenger services - the next steps. Research in Transportation Economics. 29(1), pp. 204-211. https://doi.org/10.1016/j.retrec.2010.07.025

Pittman, R. (2007). Options for Restructuring the State-Owned Monopoly Railway. Research in Transportation Economics. 20(1), pp. 179-198. https://doi.org/10.1016/S0739-8859(07)20007-1

Sheu, J. B. (2011). Bargaining framework for competitive green supply chains under governmental financial intervention. Transportation Research Part E Logistics \& Transportation Review. 47(5), pp. 573-592. https://doi.org/10.1016/j.tre.2010.12.006

Shintani, K., Imai, A., Nishimura, E., Papadimitriou, S. (2007). The container shipping network design problem with empty container repositioning. Transportation Research Part E Logistics \& Transportation Review, 43(1), pp. 39-59. https://doi.org/10.1016/j.tre.2005.05.003

Sun, Y., Lang, M. (2015). Bi-objective optimization for multi-modal transportation routing planning problem based on Pareto optimality. Journal of Industrial Engineering \& Management. 8(4), pp. 1195-1217. https://doi.org/10.3926/jiem.1562

Theofanis, S., Boile, M. (2009). Empty marine container logistics: facts, issues and management strategies. GeoJournal. 74(1), pp. 51-65. https://oi.org/10.1007/s10708-008-9214-0 